\title{
The Relationship between Teachers' Factors and Effective Teaching
}

\author{
Abdul Rahim Hamdan ${ }^{1} \&$ Chia Lai Lai ${ }^{1}$ \\ ${ }^{1}$ Faculty of Education, Universiti Teknologi Malaysia, Johor, Malaysia \\ Correspondence: Chia Lai Lai, Faculty of Education, Universiti Teknologi Malaysia, 81310 Johor Bahru, Johor, \\ Malaysia. Tel: 60-12-760-6959. E-mail: lailaichia@yahoo.com
}

Received: December 27, 2014 Accepted: January 16, 2015 Online Published: April 30, 2015

doi:10.5539/ass.v11n12p274

URL: http://dx.doi.org/10.5539/ass.v11n12p274

\begin{abstract}
This study aims to examine the relationship between three teachers' factors that's teaching experiences, type of school performing and attendance of professional development course towards effective teaching among secondary school teachers in Johor, Malaysia. A total of 322 secondary school teachers from Malaysia involved in this study. The instrument used in this study was a set of questionnaire which combined Charlotte Danielson (2007) and James H Stronge (2007) models. This quantitative study utilized survey method with stratified random sampling. Teachers' factors were tested through correlation and multiple regression analysis. The finding indicate that there are significant positive correlation between three teachers factors (teaching experiences, type of school performing and attendance of professional development course) towards secondary school teachers' effective teaching. Highest relationship towards effective teaching is attendance of professional development course $(\mathrm{r}=.676, \mathrm{p}<.05)$, following by teaching experience $(\mathrm{r}=.621, \mathrm{p}<.05)$ and type of school performing shows least relationship $(\mathrm{r}=.193, \mathrm{p}<.05)$. Besides, the regression model indicates a predictive significance by teachers' factors towards effective teaching. Hence, the findings support the conclusion that the selected factors are predictors of secondary school teachers' effective teaching. This study revealed the importances of professional development course and teaching experience compare with type of school performing. Teacher needs to always continue upgrade ourselves for practising teaching effectively. These findings also have implications for secondary school teachers and administrators to reflect and broaden the views towards effective teaching.
\end{abstract}

Keywords: teaching experience, school performing, professional development course, teacher, effective teaching

\section{Introduction}

Teaching is a unique profession which forms the human capital. Teacher is always been remembered and appreciated throughout a student learning span. In the whole of teaching process, teacher plays the role as an input in producing effective teaching and shaping the students' future. Hanushek, Kain \& Rivkin (2004) explains that teachers always serve in the frontline to change the social culture through their professional action. In Malaysia Education Blueprint 2013-2025 has shown that government put more efforts on the importance of recognizing the teaching profession in order to produce quality human capital for the country (KPM, 2013). This is because human capital as a vital base to contribute in producing and expanding the development of a country. Therefore, effective teaching is the utmost important thing to propagane through teacher serves as an educational agent who has been trusted.

In the meantime, teacher always strives to shape and produce the potential citizen who is capable to contribute the resources to the nation in the future. A teacher can learn continuously in order to gallant and complete the artistic of teaching which is complicated. This is because an effective teacher in a teaching field will always 'learn to teach' for upgrading again our teaching crafts (Fetherston, 2007). This spirit is a must for teachers in order for them to achieve the level of potential in their teaching. Nevertheless, there is no absolute formula which can be memorized by a teacher in entering the class. Effective teaching is not a process which can be uttered with a loud voice. It is a journey not only can deliver the knowledge, skill and value but also can touch the the heart and soul of the students (Chia \& Abdul Rahim, 2012). Therefore, teacher factors which involve the teaching experience, type of school performing and attendance of professional development course are keen to be survey whether they are correlated with the effective teaching as majority thinks about. This perspective will 
manage to gallant and broaden our paradigm towards effective teaching in the $21^{\text {st }}$ century educational transformation.

\subsection{Teachers' Factors and Effective Teaching}

Teacher plays an important role in the teaching process where learning takes place. This study is focus on teaching experience, type of school performing and attendance of professional course as the teachers' factors. Darling Hammond (2000) supported that teaching experience was correlated with teachers' effectiveness. It is consistent with Elliot (2010) study which involved teachers from Japan and Guatmala by using Stronge model stated that teaching experience as an important factor in effective teaching. These findings were parallel with study conducted by Magdeline (2012), teaching experience was related to teacher effectiveness because experience teacher able to modify the content during delivering the lessons. Hence, they manage to teach effectively and clearly for easy understanding of the students. Nye et al (2004) even emphasized teachers with more than three years teaching experiences were more effective than those less than three years experiences. The finding was same with Darling Hammond (2000) who had summarised many research and found that more than three years teaching experience teachers were more effective compare with less than three years experience teachers. This is due to new teacher needs some years of experience to polish and strengthen their teaching practice.

As for type of school performing, many previous studies indicated that high performing school has lots of effective teachers and provided effective teaching (Corbett, 2002; Stronge, 2007). Teachers from this type of school practised what they acquired and delivered to their students. According to Law \& Kaufhold (2009), teachers from high performing school were more confidence to their students regarding the ability of acquiring critical thinking skill compared with teachers from low performing school. Nevertheless, there were teachers from low performing school struggled with much efforts to improve their students. Chenoweth (2007) pointed out that some people would say these (low performing) schools could never be expected to teach their students to high standards. But teachers from this type of low performing school proved that with their well time management and organising resourses skills, they able to teach their students effectively and achieved teachers' expectations. Furthermore the school was like a big family to the teachers. They were active and enjoyed to teach effectively in the school. In addition, Poplin (2011) also supported with her study which involved 31 teachers from Los Angeles and found that teachers in the school self realized that it's their responsibilities to try to push the students forward. The students able to improve and achieved targerted expectation under their teachers' teaching from the low performing school.

Effective teaching also was correlated with professional development course. The professional development course plays as a key to help teachers adapt towards the changes in their teaching practice nowadays (Baiocco \& De Waters, 1998). Professional development course plays an important role to increase pedagogi content knowledge and exposure new strategy for teacher to teach more effectively. Teachers who always attend professional development courses more than eight hours were more prepared and effective compare with those who didn't attend the courses, especially in the readiness in their teaching (Holloway, 2003). However, Peckover et al (2006) disagree with the roles of professional development courses and showed their weak relationship towards effective teaching.

There were five constructs which include teaching planning, classroom management, teaching strategy, teacher attribute and professional responsibility in this study. According to Danielson (2007), teaching planning as a backstage task which organising teaching in a classroom. This effort needs well content knowledge in designing a suitable teaching for different types of students in their learning. In previous study, Misulis (1997) did supported that "regardless of the teaching model and method used, effective instruction begins with careful, thorough and organized planning on the part of the teacher" (pg. 45). Thus, teaching planning was needed to achieve the objectives of learning and teaching process. Classroom management is also important in effective teaching. This is because well classroom management able to produce an atmosphere which is conducive and harmony. Hence, such an atmosphere enables teaching and learning process more smoothly to be conducted and students can be more focus in their studies. Teachers also equired students to follow some procedures which means to supports teaching and learning process (Good \& Brophy, 2008). Meanwhile, Stronge (2007) did mentioned majority of the effective teacher admit that they emphasis on classroom rules when start schooling in order to create a systematic class procedure which can follow by the students. Consequently, safe classroom physical space will be provided under well classroom management of the teacher.

Besides, teacher needs to provide a clear explanation through teaching strategy to the student as a guide in order to make something unclear becomes clear and acceptable in a student's live (Danielson, 2007). Well 
communication between teachers and students makes the teaching process becomes more fruitful (Stronge, 2007). Divergent of questioning skill enables teachers to enhance students' high order thinking level and not just for memorizing the facts only. This is consistent with Barth (2004), appropriate questions which posted by teachers can enhance students' cognitive level to develop the concept and skill which are needed in reorganizing their previous knowledge towards the subject. In addition, flexible response from teachers makes the teaching be conducted with more effectively. The aspect of a teacher's attribute can contribute to teacher happy moods in a classroom. Hence, it affects the classroom atmosphere become more harmonious and produces implication to the space for learning and teaching take place indirectly (Nodding, 2005). Teacher's happy mood has much depends on a teacher's attribute which acts as a locomotive to interact with their students. Noblit et al (1995) stated that "caring is central to education - the glue binds teachers and students together and makes life in classrooms meaningful". A teacher who always cares of his/ her student able to make the student puts on more efforts in that particular subject. According to Long dan Hoy (2006), teachers' enthusiasm towards their content knowledge and student's need contribute positive effects in teaching practice. Professional responsibility involves communication between teacher and either the student's family or professional community to upgrade their professionalism. Haynie (2006) stated that teacher who always planning their lesson through collaboration with their peers and involved in professional community activity were more effective in their teaching. Constructive information or development which been shared and gained from professional community can be apply in teaching process and make it more meaningfully. Besides, Bafirman (2014) also pointed out that Sports, Physical Education and Health teachers with professionalism prioritized human values and were able to provide the best services in their teaching with professional manner. Thus, effective teaching as an important process where learning takes place and needs teacher as a vital input to contribute in this education world.

\subsection{Objective}

The objective of this quantitative study is to identify the relationship between teachers' factors towards effective teaching. Hence, the following research objective and null hypothesis were established to guide the present study.

i) To identify the relationship between teaching experiences, type of school performing and attendance of professional course towards effective teaching among secondary school teachers in Johor, Malaysia.

Ho1: There is no significant relationship between teaching experiences, type of school performing and attendance of professional course towards effective teaching

\section{Method}

This quantitative survey study explores the relationship between secondary school teachers' factors (teaching experiences, type of school performing and attendance of professional course) and effective teaching. The teachers' factors also were tested whether they were significant predictors for effective teaching. Hence, Statistical Package for Social Sciences (SPSS) 16.0 was used to analyse the descriptive and inferential statistics (correlation and multiple regression analysis) in this study. Variables were examined from various assumptions underlying multivariate such as linearity, normality, outliers and multicollinearity through exploratory data analysis to ensure related statistical assumptions were not violated.

\subsection{Sampling}

The population of the study was 842 secondary school teachers from 10 schools of Johor, Malaysia (5 high performing and 5 low performing schools) based on composit scores. A total of 322 samples of secondary school teachers were selected by using stratified random sampling. There were 206 Malay teachers, 77 Chinese teachers, 35 Indian teachers and 4 others races like Bidayuh and Iban teachers. The number of samples fulfilled the minimum samples saiz requirement suggested by Krejcie and Morgan (1970).

\subsection{Instrumentation}

The instrument used in this study was a set of questionnaire consisted by 64 items with 6 point likert scale. It was formed by five constructs, that's teaching planning (16 items), classroom management (10 items), teaching strategy (16 items), teacher attribute (10 items) and professional responsibility (12 items). The instrument has been reviewed by experts in this field to ensure the content validity (Parmjit et al, 2010). Besides, Rasch measurement model was used with unidimensionality $40 \%$ as minimum cutting point and unexplained varians in the $1^{\text {st }}$ contrast less than $15 \%$ for the construct validity (Azrilah, 2010). In this study, the value of unidimensionality was $57.60 \%$ and unexplained varians in the $1^{\text {st }}$ contrast only $3.6 \%$ (less than $15 \%$ ). This instrument fulfilled all the setting criteria. In addition, the alpha Cronbach coefficient also showed a high reliability index with 0.98 . Thus, the questionnaire was validated and reliable to be used in this study. 


\subsection{Exploratory Data Analysis}

Exploratory data analysis was conducted to ensure the related statistical assumptions were not violated. Variables were examined from various assumptions underlying multivariate such as linearity, normality, outliers and multicollinearity. In this study, teachers' factors fit the assumption of multivariate analysis. The scatterplots' elliptical shape denoted the scores had fulfilled the requirement of linearity and normality in multivariate (Mertler \& Vannatta, 2005). The maximum value of Cook's diatance in this study is less than 0.1 while Cook (1977) stated that the value in between 0.8 to 1.0 represent outliers. This means that no outliers need to be deleted in this study. Meanwhile according Hair et al (2010), cut off point for the value of Variance Inflation Factor (VIF) need to be less than 10 in order to detect multicollinearity problems. In this study, the values of VIF statistic are less than 10, which are in the range of 1.053 to 1.776 . Hence, we are able to conclude that there are no serious multicollinearity problems happened among the teachers' factors in this study.

\section{Results and Discussion}

\subsection{Respondents Demografic Profile}

There were 322 secondary school teachers from 10 schools of Johor, Malaysia involved in this study (5 high performing and 5 low performing schools). In term of gender, there were more female teachers, that's $68.3 \%$ compare with male teachers $(31.7 \%)$. All these respondent teachers were consisted by different unique races in Malaysia, that's Malay (206 teachers) as majority, Chinese ( 77 teachers), Indian (35 teachers) and others races like Bidayuh and Iban (4 teachers). The distribution of respondents by education level indicated that most of the respondents were bachelor degree holders $(89.8 \%$ ), while $8.7 \%$ of them possessed master degree and only $1.6 \%$ as diploma holders.

On the other hand, 161 teachers were from high performing school and others 161 teachers were from low performing school respectively. Majority of the teachers attended professional development course, however there were $11 \%$ of them didn't experience the courses. Twenty seven teachers have less than 3 years' experiences. 3-5 years teaching experiences group has 69 teachers, while 6-10 years group has 95 teachers as highest component. Besides, 11-15 years and 16-20 years teaching experiences groups were consist by 45 and 46 teachers. There were 40 teachers who have more than 20 years teaching experiences in this study.

\subsection{Correlation and Multiple Regression of Teachers' Factors and Effective Teaching}

To answer the research question, Pearson and Point Biserial correlation coefficient were used to report the results (as shown in Table 1).

Table 1. Correlation coefficient between teachers' factors and effective teaching

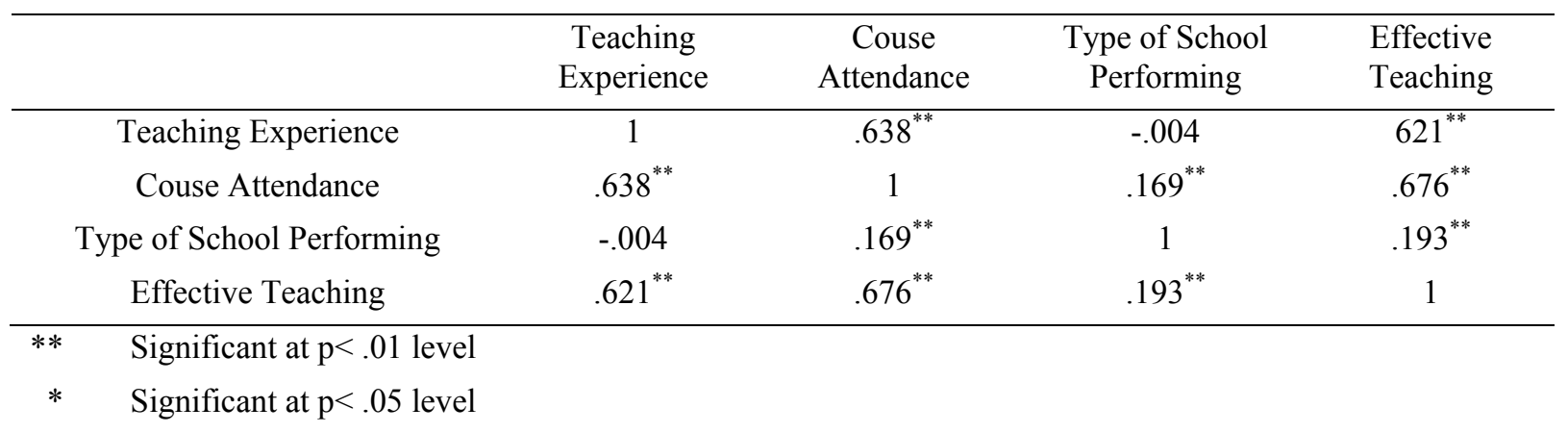

Table 1 reveals that there is a high statistically significant positive correlation between teaching experience and effective teaching $(\mathrm{r}=.621, \mathrm{n}=322, \mathrm{p}<.01)$. The statistically significant relationship indicates that as the teaching experience increase, effective teaching scores increase too. The finding is similar with Elliot (2010) who involved teachers from Japan and Guatmala in her research and found that teaching experience was important in effective teaching. It is supported by Magdeline (2012) regarding teaching experience was related to teaching effectiveness. Experienced teachers manage to adjust and simplify the content knowledge which makes the students to understand more easily.

Besides, a high statistical significant relationship was also been found between course attendance and effective teaching $(\mathrm{r}=.676, \mathrm{n}=322, \mathrm{p}<.01)$. The correlation result implies that the higher course attendance, the higher effective teaching. Finding in this study affirmed statement of Baiocco \&De Waters (1998) regarding 
professional development course as an important key for teachers to adapt towards the changes in their teaching practice. The finding is also consistent with Holloway (2003), effective teaching practice was correlated with professional development courses. Teachers who always attend professional development courses were more prepared and effective compare with those who didn't attend the courses. Thus, the finding is contradicted with Peckover et al (2006) study which found weak relationship between professional development courses in teaching practice. This is because course attendance reveals higher correlation to effective teaching compare with teaching experience in this study.

Nevertheless, type of school performing show a low statistical significant relationship with effective teaching (r $=.193, \mathrm{n}=322, \mathrm{p}<.01)$. The finding revealed different result with Corbett (2002) and Law \& Kaufhold (2009). This finding supports Chenoweth (2007) and Poplin (2011) who found that low performing school teachers also try to strive a lot to teach their students effectively. Teachers from those low performing school proved that through their well time management and organising resourses skills, they able to teach their students effectively and contribute to this big family.

Therefore, null hypothesis (Ho1) is rejected in this study. The analysis indicates that there is significant positive correlation between three teachers' factors (teaching experiences, type of school performing and attendance of professional development course) towards effective teaching among secondary school teachers in Johor, Malaysia. Highest relationship towards effective teaching is attendance of professional development course $(\mathrm{r}=.676, \mathrm{p}<.01)$, following by teaching experience $(\mathrm{r}=.621, \mathrm{p}<.01)$ and type of school performing shows least relationship $(\mathrm{r}=.193, \mathrm{p}<.01)$. Therefore, the interesting findings broaden our views and minds towards effective teaching. This finding also strengthens again the importance of teachers' attendance in professional development courses.

In order to further determine the predictors of teachers' factors towards effective teaching, stepwise multiple regression was employed. From the result as shown, we are able to know how well the teacher factors predict effective teaching among secondary school teachers. The obtained finding in Table 2 indicates that teachers' factors are predictors of effective teaching.

Table 2. Stepwise regression analysis of teachers' factors in effective teaching

\begin{tabular}{ccccccc}
\hline & $\mathbf{B}$ & $\boldsymbol{\beta}$ & $\mathbf{t}$ & Sig & $\mathbf{R}^{\mathbf{2}}$ & $\mathbf{F}$ \\
\hline Constant & 3.323 & & 33.609 & $.000^{*}$ & & \\
Course Attendance & .210 & .438 & 8.552 & $.000^{*}$ & .457 & 269.594 \\
Teaching Experience & .150 & .342 & 6.781 & $.000^{*}$ & .518 & 171.169 \\
Type of School Performing & .156 & .120 & 3.045 & $.003^{*}$ & .531 & 120.16 \\
\hline
\end{tabular}

$\mathbf{B}=$ Unstandardized multiple regression coefficient.

$\boldsymbol{\beta}=$ Standardized multiple regression coefficient

* Significant at $\mathrm{p}<.05$ level

Table 2 shown the result of stepwise multiple regression analysis with the values of $\mathrm{R}^{2}=.531$. This indicates that teachers factors in effective teaching contribute $53.1 \%$ of the variance in their effective teaching practices with $\{\mathrm{F}(3,318)=120.163, \mathrm{p}<.05\}$. This means that course attendance contribute $45.7 \%$ in effective teaching practice, while teaching experience accounted for $6.1 \%$ and type of school performing only accounted for $1.3 \%$ respectively in effective teaching. The value of $\mathrm{F}$ statistics indicates that data collected fit the model at significant level $\mathrm{p}<.05$. The regression model indicates that teachers' factors are able to significantly influence the effective teaching practice among secondary school teachers.

Furthermore, we are able to form that the regression equation for effective teaching which is consisted of:

$$
\begin{gathered}
\text { Effective teaching }=3.323+(0.210 \times \text { course attendance })+(0.15 \times \text { teaching } \\
\text { experience })+(0.156 \times \text { type of school performing })
\end{gathered}
$$

This suggests that in every 1 unit increase in course attendance, effective teaching increases by 0.21 . Besides, effective teaching increases by 0.15 and 0.156 , for every 1 unit increase in teaching experience and type of school performing. This means that course attendance as the best predictor which contributes in secondary school teachers' effective teaching, following by teaching experience and type of school performing. 
Consequently, the regression model reveals that the selected teachers' factors are significantly able to predict secondary school teachers' effective teaching.

On the other hand, the value of VIF statistic were less than 10 (VIF $<10)$, that's in the range of 1.053 to 1.776 . As a result, we are able to conclude that there are no serious multicollinearity problems among the predictors' variables in this study. Therefore, it's rational to say that the predictor variables entered in this regression model present their own unique characteristics to explain the contribution in predicting effective teaching. The regression model indicates a predictive significance by these three teachers' factors towards effective teaching. Once again, the findings support and confirm the conclusion that the teachers' factors (course attendance, teaching experience, type of school performing) are predictors of secondary school teachers' effective teaching.

\section{Conclusion and Implication}

As parts of ongoing research in secondary school teaching, this article intended to identify the relationship between teachers' factors, that's teaching experience, type of school performing and attendance of professional development course with effective teaching. Furthermore the best predictor is obtained for the secondary school teachers' effective teaching. The findings provide constructive information and have implication to enlighten either administrators or teachers about the importance of professional development courses. From the insights provided, administrators manage to plan and conduct appropriate alternatives to help in strengthening teachers' effecting teaching. Teachers need to construct and upgrade knowledge continuously through attending professional development courses to improve practising in effective teaching.

Nevertheless, teaching experiences also can be accumulated by years to contribute as an extra valuable variable in teaching lives (Chia \& Abdul Rahim, 2014). Experienced teachers' contributions are appreciated and hope can be shared with their peers or new teachers about their experiences in teaching line. This current study also lights up teachers' spirit especially those from low performing school to continue with their efforts without burn out along their teaching journey. Type of school performing is not much important link with effective teaching as majority think about. In addition, this finding enlighten parents and others parties who related to education about the importance of professional development course and teaching experience compare with type of school performing as assumed for all this while. "Every school can be a good school and every teacher can be an effective teacher." As a teacher, we need to construct ourselves continuously and teach effectively whatever and wherever we can because every student deserves to gain an effective teaching class and enjoy their learning for educational sustainability in the $21^{\text {st }}$ century.

\section{Acknowledgements}

The authors would like to express sincere gratitude and appreciation to the teachers who were involved in this study.

\section{References}

Aziz, A. A. (2010). Rasch Model Fundamentals: Scale Construct and Measurement Structure. Kuala Lumpur: Integrated Advance Publishing.

Bafirman. (2014). Influence of Sports, Physical Education and Health Teacher Professionalism in Developing Students' Character. Asian Social Science, 10(5), 7-11. http://dx.doi.org/10.5539/ass.v10n5p7

Baiocco, S. A., \& DeWaters, J. N. (1998). Successful teaching: Problem-solving strategies. Needham Heights, MA: Allyn \& Bacon.

Barth, R. S. (2004). Learning by Heart. San Francisco: Jossey-Bass.

Chenoweth, K. (2007). "It's being done:" Academic success in unexpected schools. Cambridge, MA: Harvard Education Press.

Chia, L. L., \& Abdul Rahim, H. (2012, October 7-9). Pengajaran Efektif dan Kerangka Untuk Pengajaran. Paper presented at the National Seminar of Malaysian Education Dean Council (MEDC) 2012, Johor Bahru Malaysia.

Chia, L. L., \& Abdul Rahim, H. (2014). Secondary School Teachers' Effective Teaching Practice. Journal of Education and Practice, 5(15), 127-133.

Cook, R. D. (1977). Detection of Influential Observation in Linear Regression. Technometrics, 19(1), 15-19. http://dx.doi.org/10.2307/1268249

Corbett, D., \& Wilson, B. (2002). What urban students say about good teaching. Educational Leadership, 60(1), $18-22$. 
Danielson, C. (2007). Enhancing professional practice: A framework for teaching (2nd ed.). Alexandria, VA: ASCD.

Darling-Hammond, L. (2000). Teacher quality and student achievement: A review of state policy evidence. Education Policy Analysis Archives, 8(1), 1- 44. http://dx.doi.org/10.14507/epaa.v8n1.2000

Elliott, B. L. (2010). Effective Teacher characteristics: A Two Nation Causal Comparative Study. Dissertation Walden University: UMI Dissertation Publishing.

Feetherston, T. (2007). Becoming an effective teacher. Australia: Thomson Learning.

Good, T. L., \& Brophy, J. E. (2008). Looking in classroom. USA: Pearson Education, Inc.

Hair, J. F. Jr., Black, W. C., Babin, B. J., \& Anderson, R. E. (2010). Multivariate Data Analysis (7th ed.). Upper Saddle River, New Jersey: Pearson Education Inc.

Hanushek, E. A., Kain, J. F., \& Rivkin, J. G. (2004). Why Public School Lose Teachers. Journal of Human Resource, 39(2), 326-354. http://dx.doi.org/10.14507/epaa.v8n1.2000

Haynie. (2006). Effective Biology teaching: A value-added instructional improvement analysis model. Retrieved from http://www.wcpss.net/evaluation-research

Holloway, J. H. (2003). Sustaining experienced teachers. Educational Leadership, 60(8), 87-89.

Krejcie, R. V., \& Morgan, D. W. (1970). Determining size for research activities. Educational and Psychological Measurement, 30, 607-610.

Law, C., \& Kaufhold, J. A. (2009). An analysis of the use of critical thinking skills in reading and language arts instruction. Reading Improvement, 46(1), 29-34.

Long, J., \& Hoy, A. (2006). Interested Instructors: A composite portrait of individual differences and effectiveness. Teaching and Teacher Education, 22, 303-314. http://dx.doi.org/10.1016/j.tate.2005.11.001

Magdeline anak Nor. (2012). Pengetahuan Pedagogi Kandungan dan Masalah Pengajaran Guru Bahasa Iban di Sekolah Menengah Sarawak. Jurnal Teknologi, 58, 71-78.

Mertler, C. A., \& Vannatta, R. A. (2005). Advance and multivariate statistical methods (3rd ed.). Glendale, CA: Pyrczak Publishing.

Ministry of Education. (2013). Malaysia Education Blueprint 2013-2025. Putrajaya: Ministry of Education.

Misulis, K. (1997). An useful tool for instructional planning. Contemporary Education, 59(1), 45-47.

Noblit, G. W., Rogers, D. L., \& McCadden, B. M. (1995). In the meantime: The possibilities of caring. Phi Delta Kappan, 76(9), 680-685.

Noddings, N. (2005). What does it means to educate the whole child? Educational Leadership, 63(1), 8-13.

Nye, B., Konstantopoulos, S., \& Hedges, L. V. (2004). How large are teacher effects? Educational Evaluation and Policy Analysis, 26, 237-257. http://dx.doi.org/10.3102/01623737026003237

Parmjit, S., Chan, Y. F., Gurnam, K. S., \& Ranjit, K. (2010). Panduan Komprehensif Penulisan Cadangan Penyelidikan. Shah Alam: Penerbitan Universiti Teknologi Mara.

Peckover, R. B., Peterson, S., Christiansen, P., \& Covert, L. (2006). A constructivist pathway to teacher leadership. Academic Exchange Quarterly, 10(2), 136-140.

Poplin, M. (2011). Highly Effective Teachers in Low Performing Urban Schools. The Claremont Letter, 6(1), $1-6$.

Stronge, J. H. (2007). Qualities of effective teachers. Alexandria, VA: Association for Supervision and Curriculum Development.

\section{Copyrights}

Copyright for this article is retained by the author(s), with first publication rights granted to the journal.

This is an open-access article distributed under the terms and conditions of the Creative Commons Attribution license (http://creativecommons.org/licenses/by/3.0/). 